\section{Gulf war and sanctions}

SIR - On the day Iraq invaded Kuwait, I completed my thirteenth year as an associate professor at the medical school of Kuwait University. I was one of a group of expatriates who joined the university in 1977 and with the Kuwaiti staff helped to establish the medical school.

During the past 13 years, we watched the medical school grow into a well-established scientific institution. It has always set very high standards for both students and research. This was recognized by many international institutions as well as by scientists and academic visitors.

The medical school also established a sound and well-designed postgraduate programme. This was possible because of excellent planning and the availability of up-todate equipment and materials as well as a good infrastructure.

The medical school had held an international scientific meeting every three years and symposia and workshops were also held every year in all branches of basic and clinical sciences and the proceedings of these meetings were published. This scientific activity re-emphasizes not only the faculty's reputation for outstanding original research but also that the research is directly applicable to the needs of Kuwait and the Gulf region.

The scientific community all over the world was shocked and appalled by the looting, destruction and removal of virtually every piece of equipment and materials from scientific and educational institutions in $\mathrm{Ku}$ wait.

Nothing similar had ever been seen anywhere in the civilized world. It is well known that Saddam Hussein's regime is despotic and tyrannical and rules by fear. But what I cannot comprehend is the dishonesty and lack of scientific decency of the Iraqi professors who were personally involved in the systematic dismantling of the various scientific institutions around Kuwait (see Nature 347, 420; 1990 \& 349, 450; 1991).

I strongly believe that the scientific community should impose sanctions on scientific contributions from Iraq for some time to come, to force Iraq to pay for the equipment that was removed from Kuwait.

Abdalla O. Elkhawad

University of Southampton,

Department of Physiology \&

Pharmacology,

Bassett Crescent East,

Southampton SO9 3TU, UK

SIR - While it seems unlikely, from the evidence reported, that the Iraqi 'baby milk' factory was a biological weapons assembly plant (see Nature 350, 117; 1991), use of the tone powders and more complex formula- to a separate facility for cultivation of the microorganisms used in the manufacture of biological weapons. The apparent lack of microorganisms or their products at the Iraqi site does not exclude the possibility that the factory was indirectly involved in the production of biological weapons.

Scott D. CoBOurn

Center for Bioorganic Chemistry,

Research Triangle Institute,

Research Triangle Park,

North Carolina 27709, USA

\section{Infectious paradigm}

SIR - Walter Gilbert's vision (Nature 349 , $99 ; 1991)$ that the paradigm shift provoked by the human genome project may free small science from DNA technology is convincing, but is there not a danger that the same paradigm will be applied to small science itself? So much can be seen in the criteria used in the determination of research grant applications - the certainty of a promised result, and of an advertised timetable, for example.

What is happening is that biologists are muddling together two activities which, in the physical sciences, are separate - scientific and engineering research. Both demand ingenuity and perseverance, but they are different.

Research in physics, striving for generalizations, reflects the curiosity of individuals, cannot be totally planned and does not guarantee interesting results. Engineering research, by contrast, seeks information specific to one group of phenomena that can then be put to practical use. The work is varied - the thermal conductivity of ceramics or the execution time of algorithms - and usually involves social or even corporate interests, but the methods are known, the timetables calculable and the outcomes foreseeable.

Traditionally, that difference has been reflected in the practice of funding agencies. Engineering projects have been awarded contracts, science research projects have won grants.

Medicine, the application of biological knowledge to the preservation of human health, is biology's analogue of engineering. None of us disputes that the genome project will benefit medicine, but we should not lightly assume that all of the coming decade's addition to our understanding of biology will be a by-product of molecular medicine. And we should beware of unwittingly subjecting biologists to selection pressures that only engineering research can meet.

\section{British science}

SIR - Terence Kealey (Nature 350, 370; 1991) raises two interesting issues about the structure and performance of British science, both of which relate to studies undertaken by the Science and Engineering Policy Studies Unit (SEPSU) in recent years.

One issue concerns the interpretation of bibliometric data, on which some of Kealey's comments are misleading. First, the Institute for Scientific Information (ISI) did indeed increase its journal coverage by nearly 40 per cent between 1975 and 1982, but one cannot infer from this that the global population of journals also increased by 40 per cent, still less that Britain "increased its numbers of papers by some 30 per cent". The 40 per cent figure is primarily a statement about ISI, not about world output. Second, we at SEPSU showed in our original study that both the 1973 fixed journal set and a larger set defined in 1981 give the same figure -8.3 per cent for the UK share of world output in 1982. We did not 'ignore' the journals established after 1973: we demonstrated that they did not materially alter our conclusions. Third, to the extent that research is a competitive business, market share matters as well as absolute volume.

The second and more important issue is the extensive change to the structure of British science that has occurred over the past $10-15$ years. Kealey very rightly draws attention to the 'privatization' of British science. One consequence of this has been a switch from long-term to project funding and, with it, the rapid growth in the number of short-term academic staff that Kealey mentions. However, it is unsafe to draw too many comforting conclusions from this development: nearly two-thirds of these shortterm academic staff are below $\mathrm{PhD}$ status and would not normally be regarded as independent researchers, while the remainder have uncertain career prospects. Moreover, while it is certainly true that industrial and charitable funding of university scientific research has doubled in recent years, it still constitutes only 35 per cent of total external funding of university research, or 18 per cent of UFC + external funding.

Drawing in part on earlier SEPSU work, the Royal Society is now conducting a major inquiry into long-term issues in science policy, to think through the implications of the above, and other, structural changes and to identify some of the policies that will be needed to sustain the health of British science into the next century (see Nature 349, 183; 1991). Anyone wishing to contribute to the inquiry is invited to write to the president, Sir Michael Atiyah (The Royal Society, 6 Carlton House Terrace, London SW1Y 5AG). factory for the production of the bacteriological media required for the production of such weapons is a very real possibility. Peptions could be easily produced and shipped

Douglas E. Brash Department of Therapeutic Radiology, Yale University, 333 Cedar Street,

New Haven, Connecticut 06510, USA

\section{Science and Engineering \\ Policy Studies Unit, \\ 6 Carlton House Terrace, \\ London SW1Y 5AG, UK \\ Peter Collins}

NATURE · VOL $351 \cdot 2$ MAY 1991 